\title{
Pohjoista laatua erikoiskasveilla
}

Rainer Peltola ${ }^{1}$, Antti Hannukkala ${ }^{2}$,Bertalan Galambosi ${ }^{3}$, Jaana Väisänen ${ }^{4}$

1. MTT, Kasvintuotannon tutkimus, Eteläranta 55, 96300 Rovaniemi, rainer.peltola(at)mtt. $f i$

2. MTT, Kasvintuotannon tutkimus, Eteläranta 55, 96300 Rovaniemi, antti.hannukkala(at)mtt.fi

3. MTT, Kasvintuotannon tutkimus, Lönnrotink. 3, 50100 Mikkeli, bertalan.galambosi(at)surffi.fi

4. OAMK, Luonnonvara-alan yksikkö, Kotkantie 1, 90250 Oulu, jaana.vaisanen(at)oamk. $f i$

\section{Tiivistelmä}

Kuminan tuotantoa voidaan pitää suomalaisen erikoiskasvituotannon menestystarinana ja osoituksena siitä, että pohjoisen vaativat kasvuolot voidaan kääntää myös kilpailueduksi silloin kun tuotannon laadulla on suuri merkitys. Menestyvä ja laajamittainen erikoiskasvituotanto on kuitenkin mahdollista vain jos maatilojen koneketjut ja osaaminen ovat mahdollisimman suoraan sovellettavissa.

Pohjoisiin oloihin soveltuvia erikoiskasveja ovat kuminan lisäksi mm. väinönputki (Angelica archangelica), siankärsämö (Achillea millefolium) sekä piharatamo (Plantago major). Näitä kasveja sekä niistä jalostettuja uutteita ja eteerisiä öljyjä käytetään $\mathrm{mm}$. mausteina, kosmetiikka- ja hyvinvointituotteissa sekä lisäravinteina. Maa- ja elintarviketalouden tutkimuskeskuksen Rovaniemen yksikössä tutkittiin näiden erikoiskasvien peltoviljelytekniikoita.

Väinönputken tuotannossa tutkittiin lisäysmenetelmiä, rikkakasvintorjuntaa, sadonkorjuutekniikoita sekä alkuperän vaikutusta juurisadon määrään ja laatuun. Syyskylvön tarkkuus on merkittävä hoitotöiden määrään vaikuttava tekijä. Syyskylvöä käytettäessä pneumaattisen kylvökoneen käyttö on suositeltavaa, sillä hyvän juurisadon edellytyksenä on riittävän harva ja tasainen taimiväli. Syyskylvöt on mahdollista tehdä myös kasvatuskennoihin joista taimet istutetaan seuraavana keväänä. Tämä kuitenkin johtaa juurten sykeröitymiseen mikä vaikeuttaa sadonkorjuuta ja sadon jatkokäsittelyä. Rikkakasvit torjuttiin ensimmäisessä kokeessa luomutuotannon sääntöjä noudattaen liekittämällä, haraamalla, multaamalla ja kitkemällä. Toisessa rikkakasvien torjuntakokeessa tutkittiin kahden herbisidin, metributsiinin ja linuronin käyttöä. Näistä linuroni soveltuu väinönputkelle, virallista hyväksyntää ei kuitenkaan ole. Sadonkorjuussa kokeiltiin perunannostokonetta, joka kuitenkin katkoi syvälle ulottuvat pääjuuret sekä ohuita sivujuuria jättäen noin $10-20 \%$ juurimassasta maahan. Väinönputken laskennallinen juurisato oli $15-20 \mathrm{th} \mathrm{ha}^{-1}$ (tuorepaino) mikä on samaa luokkaa kuin tärkeimmillä tuotantoalueilla Keski- ja Itä-Euroopassa. Juuriöljyn fellandreenipitoisuus, mikä on tärkein öljyn laatukriteeri, vaihteli voimakkaasti eri alkuperää olevissa kasveissa.

Siankärsämön ja piharatamon viljelyssä rikkakasvien hallinta on keskeisellä sijalla. Molemmat kasvit ovat pienisiemenisiä ja itävät hitaasti, jolloin ne jäävät helposti rikkojen jalkoihin. Tämän takia on hyvä torjua hankalat rikkakasvit ennen näiden lajien viljelyn aloittamista. Rikkakasvien torjuntakokeissa tutkittiin herbisidejä, katteita, harausta ja liekitystä. Herbisideistä linuroni ja aklonifeeni osoittautuivat tehokkaiksi. Metributsiinin teho ei ole ollut riittävän suuri. Katteet ja mekaaniset menetelmät ovat työläitä ja teholtaan kemiallista torjuntaa huonompia joten peltomittakaavaan ne soveltuvat huonosti. Lannoituskokeissa typen määrän lisäys ei johtanut merkittäviin sadonlisäyksiin.

\section{Asiasanat}

Erikoiskasvi, viljelytekniikka, väinönputki, Angelica archangelica, siankärsämö, Achillea millefolium, piharatamo, Plantago major 


\title{
Johdanto
}

Suomessa harjoitetaan maataloutta muuhun Eurooppaan verrattuna huonommissa ilmastoolosuhteissa. Äärevät ilmasto-olot ovat kuitenkin käännettävissä kilpailueduiksi silloin kun tuotteelta vaaditaan erityisominaisuuksia. Esimerkkeinä tällaisista maataloustuotteista ovat mallasohra ja kumina. Kuminan viljelypinta-ala oli vielä 90 - luvulla olematon, 2000 - luvulla se on ollut jopa yli 20 000 hehtaaria. Nykyään Suomessa tuotetaan noin neljäsosa koko maailman kuminasta.

Pohjoisiin oloihin soveltuvia erikoiskasveja ovat kuminan lisäksi mm. väinönputki (Angelica archangelica), siankärsämö (Achillea millefolium) sekä piharatamo (Plantago major). Näitä kasveja sekä niistä tuotettuja uutteita ja eteerisiä öljyjä käytetään $\mathrm{mm}$. mausteina, kosmetiikassa, hyvinvointituotteissa sekä lisäravinteina. Näidenkin kasvien kannattava viljely edellyttää riittävän suurta, peltomittakaavaista tuotantoa. Kannattavan peltomittakaavaisen tuotannon edellytyksenä on, että olemassa olevat koneketjut ja osaaminen ovat mahdollisimman suoraan sovellettavissa uusiin tuotantosuuntiin. Jos uuden viljelykasvin viljelymenetelmät edellyttävät raskaita laiteinvestointeja kynnys uusien kasvien tuotannon aloittamiseen luonnollisesti nousee.

Näiden erikoiskasvien tuotannon kehittämiseksi Maa- ja elintarviketalouden tutkimuskeskuksen Rovaniemen yksikön Apukan koetilalla sekä Mikkelin yksikön Karilan koetilalla tutkittiin kylvö- ja istutusmenetelmiä, rikkakasvintorjuntaa, sadonkorjuutekniikoita, juurisadon varastointia ja eri alkuperää olevien kasvikantojen satoisuuden ja kasvikemiallisten ominaisuuksien eroja.

\begin{abstract}
Aineisto ja menetelmät
Väinönputken viljelymenetelmien tutkimusalat perustettiin Rovaniemelle, Maa- ja elintarviketalouden tutkimuskeskuksen Apukan koetilalle $\left(66^{\circ} 3^{\prime} \mathrm{N}, 26^{\circ} 1^{\prime} \mathrm{E}\right)$ sekä tutkimuskumppanin pellolle Tornion Kukkolaan $\left(65^{\circ} 6^{\prime} \mathrm{N}, 24^{\circ} 4^{\prime} \mathrm{E}\right)$. Kokeissa käytettiin väinönputken Utsjoen kantaa, jonka lisäysmateriaali oli peräisin Taivalkoskelta. Osalle harjuviljelynä toteutetuista koealoista siemenet kylvettiin syksyllä 2010 ja osalle istutettiin taimet keväällä 2011. Taimet olivat siementaimia edellisen syksyn kylvöstä. Kylvö- ja istutustiheydet olivat noin $13-19 \mathrm{~cm}$ (syyskylvö) sekä $15-18 \mathrm{~cm}$ ja $30 \mathrm{~cm}$ (taimilisäys). Rikkakasvien torjuntamenetelmistä kokeiltiin liekitystä, harausta ja multausta sekä kahta herbisidiä, metributsiinia ja linuronia. Syyskylvetyissä riveissä riviväliä harvennettiin harauksen yhteydessä, mikä alensi juurisatoa. Sadonkorjuussa (2. vuoden sato) kokeiltiin perunannostokonetta. Viljelykokeiden tuloksista tässä yhteydessä tarkastellaan juurisadon määrää sekä juurten kemiallista laatua.

Varastointikokeissa 2. vuoden pestyä ja multaista juurisatoa säilytettiin $1-4^{\circ} \mathrm{C}$ :een lämpötilassa 161 vrk rei'itetyissä muovisäkeissä. Varastoinnin aikana seurattiin juurten painohäviötä koko varastointiajan sekä juurten kemiallista laatua 42 vrk:n varastointiaikaan saakka.

Kantavertailuja varten perustettiin koealat Maa- ja elintarviketalouden tutkimuskeskuksen Karilan koetilalle Mikkeliin $\left(61^{\circ} 4^{\prime} \mathrm{N}, 2^{2} 7^{\circ} 2^{\prime} \mathrm{E}\right)$ sekä Lapin Ammattiopiston Metsäruusuntien opetusmaatilalle Rovaniemelle $\left(66^{\circ} 3^{\prime} \mathrm{N}, 25^{\circ} 4^{\prime} \mathrm{E}\right)$. Koealoilla viljeltiin väinönputken lappilaisia luonnonkantoja sekä Unkarista peräisin olevaa viljelykantaa. Vertailussa tutkittiin juurisatojen määriä sekä kemiallista laatua.
\end{abstract}

Siankärsämön ja piharatamon viljelymenetelmien tutkimusalat perustettiin Apukan koetilalle vuonna 2011. Käytetty siemenmateriaali oli siankärsämöllä saksalaista Alba - lajiketta, piharatamolla Kemijärven Ketolassa kasvatettua kantaa. Lannoituskokeet perustettiin yksilökokeena Mypex katteeseen rikkakasviongelmien välttämiseksi. Koealoilla käytettiin kolmea typpilannoitustasoa $(0,40$ ja $80 \mathrm{~kg} \mathrm{~N} \mathrm{ha}{ }^{-1}$ ). Rikkakasvien torjuntamenetelmistä tutkittiin herbisidejä (aklonifeeni, linuroni ja metributsiini) sekä koivutislettä, katteita, harausta ja liekitystä. Kaikki käsittelyt tehtiin perustamisvuotena ennen taimettumista. Liekitys-haraus -koejäsenissä kylvörivien väli oli $24 \mathrm{~cm}$ ja muissa koejäsenissä $12 \mathrm{~cm}$. Koealoilta määritettiin rikkakasvien peittävyys. Siankärsämöllä määritettiin kaksi kertaa kasvukaudessa korjatun versosadon määrä, piharatamolla siemensato.

\section{Tulokset ja tulosten tarkastelu}

Väinönputken viljelykokeissa saavutettiin syyskylvöillä $16900 \quad \mathrm{~kg} \mathrm{ha}^{-1}$ (tuorepaino) sato. Istutustaimilla sato oli $21700 \mathrm{~kg} \mathrm{ha}^{-1} 15-18 \mathrm{~cm}: \mathrm{n}$ istutusvälillä ja $16400 \mathrm{~kg} \mathrm{ha}^{-1} 30 \mathrm{~cm}: \mathrm{n}$ istutusvälillä. Käytössä ei ollut pneumaattista kylvökonetta, minkä takia syyskylvetyissä kasvustoissa taimitiheys muodostui epätasaiseksi. Paikoitellen riveissä oli sekä aukkoisuutta että taimiryppäitä. Taimilisätyillä kasveilla havaittiin juurten sykeröitymistä mikä vaikeuttaa juurisadon korjuuta ja kauppakunnostusta. Tarkkuuskylvö syksyllä lienee hoito- ja kauppakunnostustöiden minimointia 
tavoiteltaessa kevätistutusta parempi vaihtoehto. Erot satotasoissa johtunevat lähinnä syyskylvetylle kasvustoille tehdystä rivivälien harvennuksesta. Lisäystekniikalla ei ollut vaikutusta juuren kemialliseen laatuun, mutta kasvupaikalla oli (Kuva 1.). Juurisadon suuruus (3 $300-4300 \mathrm{~kg} \mathrm{ha}^{-1}$ kuiva-aineeksi muunnettuna) on kilpailukykyinen esimerkiksi Saksan $2000-6000 \mathrm{~kg} \mathrm{ha}^{-1}$ satotasoihin verrattuna (Ebert 1982, Bomme 2001).

Kuva 1. Väinönputken juuriöljyn pääkomponettien (fellandreeni, pineeni $=$ pin, limoneeni $=\lim$ ja kareeni $=$ kar) osuudet eri lisäysmenetelmillä ja eri kasvatuspaikoilla tuotetussa väinönputken juuressa.

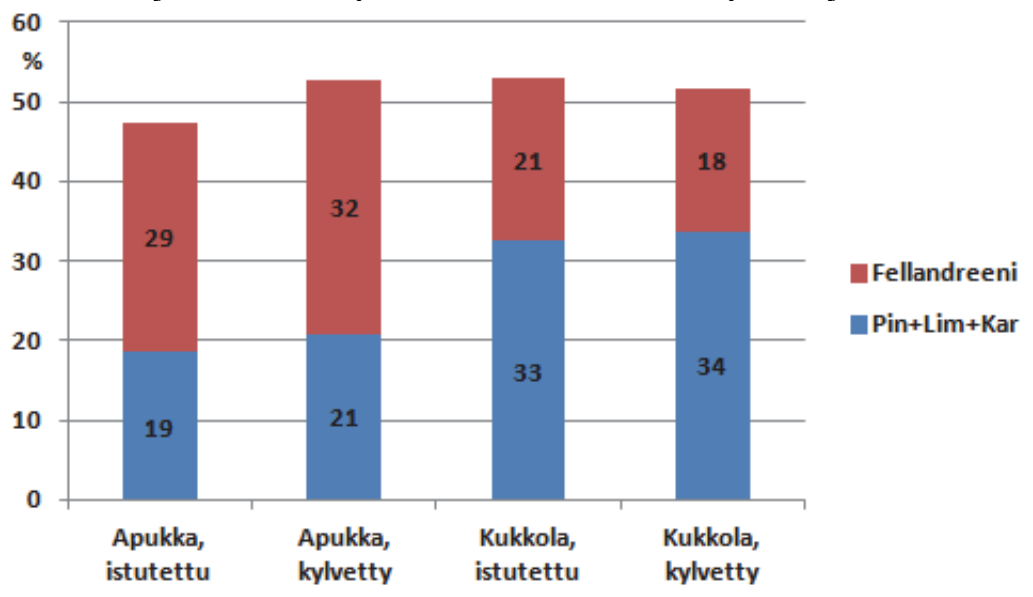

Tutkituista herbisideistä linuroni soveltui väinönputkelle, metributsiinia taimet eivät kestäneet. Virallista hyväksyntää linuronilla ei kuitenkaan ole. Rikkakasvien peittävyyttä ei määritetty, mutta siankärsämön ja piharatamon rikkakasvikokeissa todettiin linuronin tehoavan hyvin alueella esiintyviin rikkoihin. Luomutuotantoon soveltuvista rikkakasvien torjuntamenetelmistä väinönputkelle soveltuivat ensimmäisenä kasvatusvuonna haraukset yksirivisellä kiekkoharalla, multaus kahdesti kasvukauden aikana sekä rivikitkentä. Toisena kasvatusvuotena kasvusto muodostui peittäväksi jo heinäkuun alkupuolella. Koeala mullattiin vain kerran kesäkuussa, muuta rikkakasvintorjuntaa ei käytetty. Näiden toimenpiteiden vaatima laskennallinen työmäärä on noin $80-120 \mathrm{~h} \mathrm{ha}^{-1}$ kun verrokkina käytetään luomukeräkaalin ja -sipulin tuotantomenetelmiä (Ekbladh ym. 1993)

Juurisadon korjuussa kokeiltiin perunannostokonetta, mikä kuitenkin aiheutti $10-20 \%$ satotappiot juurten katkeilun takia. Etenkin pääjuureen kiinnittyneet ohuemmat sivujuuret jäivät maahan. Juurisadosta tislattavan öljyn määrään tällä on suuri merkitys, koska sivujuurten öljypitoisuus on yli kaksinkertainen pääjuureen verrattuna (Galambosi 2006).

Varastointikokeissa havaittiin vähäinen painohäviö (Kuva 2.). Multaisina varastoidut juuret todettiin vaikeiksi pestä, joten juuret on syytä varastoida pestyinä vaikka painohäviö onkin hieman suurempi. Juuriöljyn koostumuksessa ei havaittu merkittäviä muutoksia 42 vrk:n varastoinnin aikana (Kuva 3a ja 3b.). Pitkäaikainenkin varastointi ennen juurten edelleen prosessointia on siis mahdollista.

Kuva 2. Väinönputken juurten prosentuaalinen tuorepainohäviö varastoinnin aikana multaisina ja pestyinä varastoiduissa juurissa.

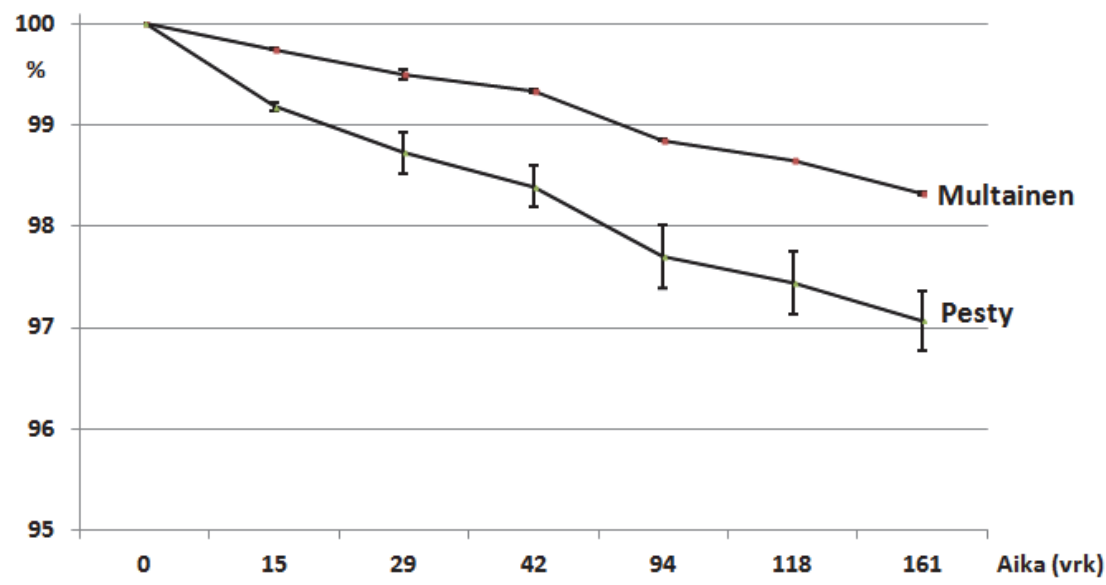


Kuvat 3a ja 3b. Väinönputken juuriöljyn pääkomponettien (fellandreeni, pineeni $=$ pin, limoneeni $=\lim$ ja kareeni $=$ kar) osuuksien muutokset pestynä ja multaisena varastoidussa juuressa.

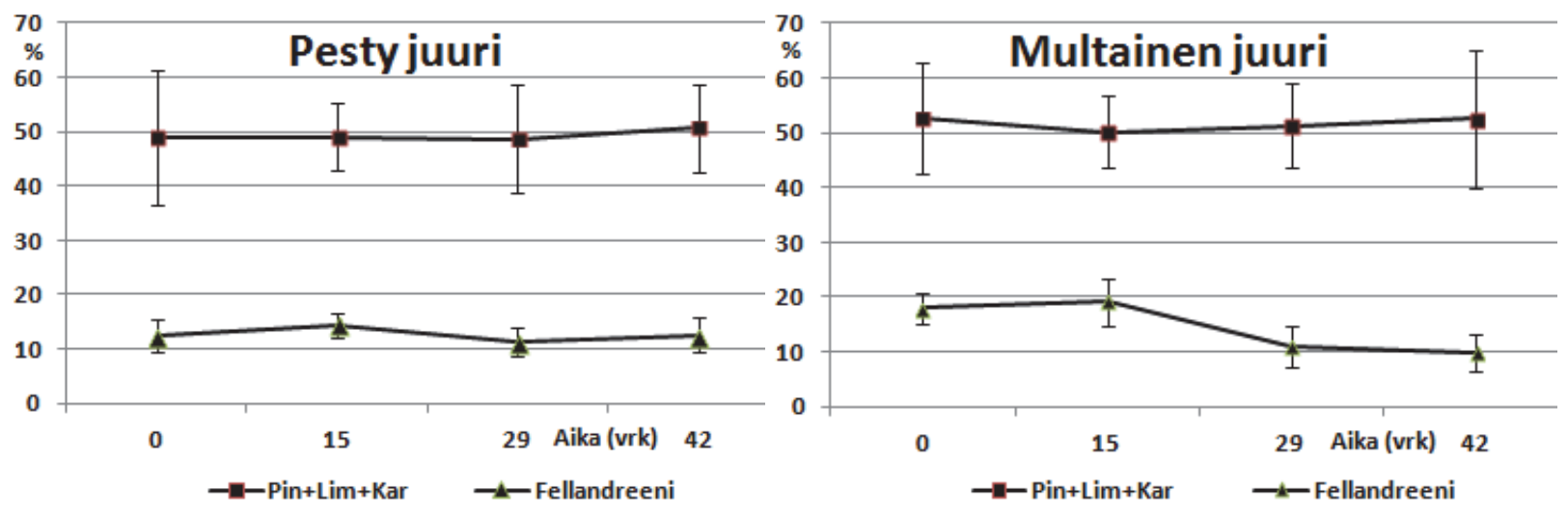

Kantavertailuissa havaittiin suuria eroja laskennallisissa hehtaarisadoissa (Kuva 4.) sekä juuriöljyn hehtaarikohtaisissa saannoissa (Kuva 5.). Tutkituista kannoista viittä viljeltiin sekä Mikkelissä että Rovaniemellä. Näistä viidestä kannasta vain yhdellä hehtaarisato oli korkeampi Mikkelissä kuin Rovaniemellä viljeltynä. Mikkelin Rovaniemeä pitempi kasvukausi ja kasvukauden korkeampi keskilämpötila ei siis vaikuta väinönputken juurisadon suuruuteen. Myös laskennallinen hehtaarikohtainen juuriöljysaanto oli yhtä kantaa lukuun ottamatta suurempi Rovaniemellä viljellyissä kannoissa Mikkelissä viljeltyihin kantoihin verrattuna.

Kuva 4. Eri alkuperää olevien väinönputkikantojen hehtaarisadot ( $\mathrm{kg} \mathrm{ha}{ }^{-1}$ t.p.) kahdessa eri paikassa (Mikkeli ja Rovaniemi) viljeltyinä.

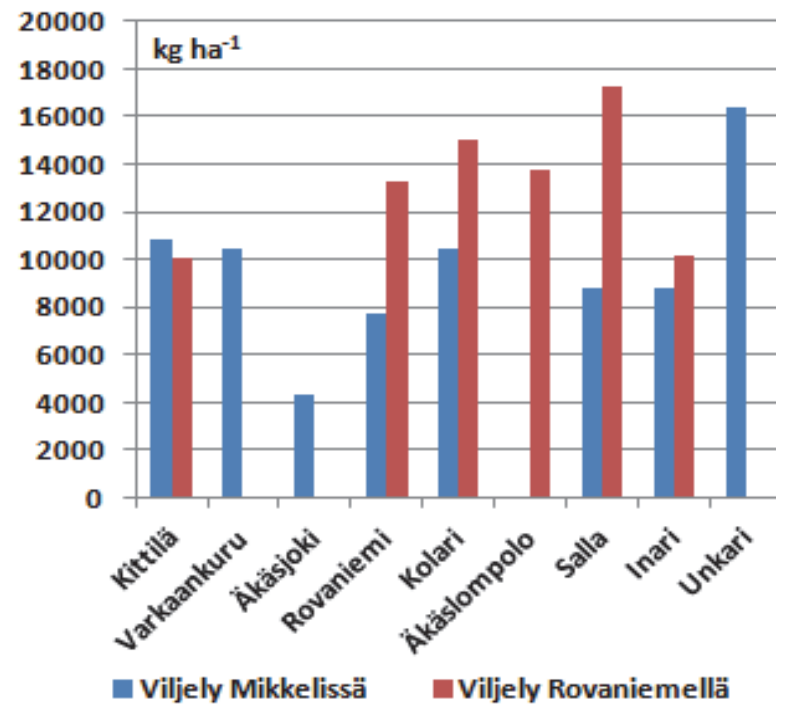

Kuva 5. Eri alkuperää olevien väinönputkikantojen hehtaarikohtaiset juuriöljysaannot ( $\mathrm{kg} \mathrm{ha}^{-1}$ t.p.) kahdessa eri paikassa (Mikkeli ja Rovaniemi) viljeltyinä.

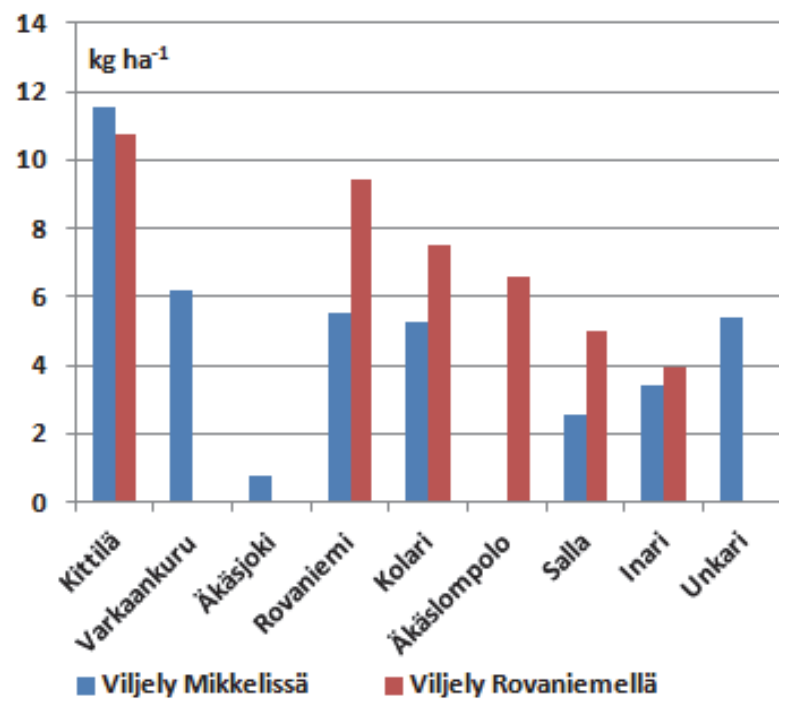

Juuriöljyjen koostumuksissa oli erittäin suuria eroja (Kuva 6.). Äkäslompolosta peräisin olevan väinönputken juuriöljyssä fellandreenin pitoisuus oli peräti $46 \%$ ja alhaisinkin Lapista peräisin olevan väinönputken juuriöljyn fellandreenipitoisuus oli $15 \%$. Havainto on merkittävä, koska fellandreenipitoisuutta pidetään yleisesti juuriöljyn tärkeimpänä laatukriteerinä (Galambosi 2006). Unkarista peräisin olevan väinönputkikannan juuriöljypitoisuus jäi niinkin alhaiseksi kuin $2 \%$. Juuriöljyn muista pääkomponentista pineeni ja limoneeni tuovat aromiin ei-toivottua, kitkerää terpeenivivahdetta ja kareenin hapettumistuotteilla on allergisoivia ominaisuuksia (Galambosi 2006). Näiden ei-toivottujen komponenttien pitoisuus oli alhaisin Äkäslompolosta peräisin olevassa väinönputkessa. 
Kuva 6. Väinönputken juuriöljyn pääkomponettien (fellandreeni, pineeni $=$ pin, limoneeni $=\lim$ ja kareeni $=$ kar) osuudet eri alkuperää olevissa väinönputkissa.

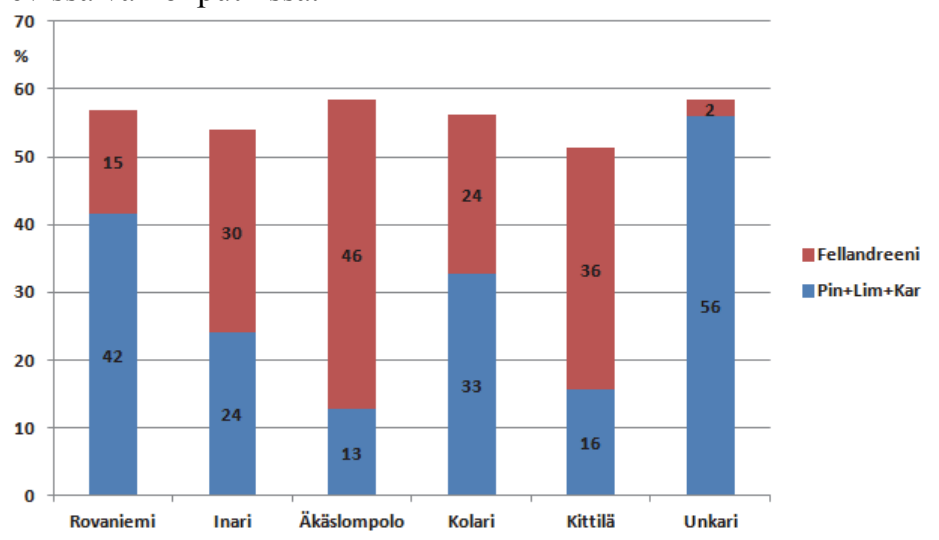

Siankärsämöstä korjattiin kaksi versosatoa sekä 2012 että 2013. Kasvukaudella 2012 toista satoa ei lannoitettu, kesällä 2013 toiselle sadolle annettiin lisätyppeä $20 \mathrm{~kg} \mathrm{ha}^{-1}$ (Kuva 7.) Typpilannoitus nosti ensimmäisen sadon määrää molempina vuosina, kasvukauden toiseen satoon sillä ei ollut vaikutusta. Vaikka satoerot näyttävät isoilta, ne eivät ole tilastollisesti merkittäviä.

Kuva 7. Typpilannoituksen vaikutus siankärsämön versosatoon Rovaniemellä 2012 ja 2013.
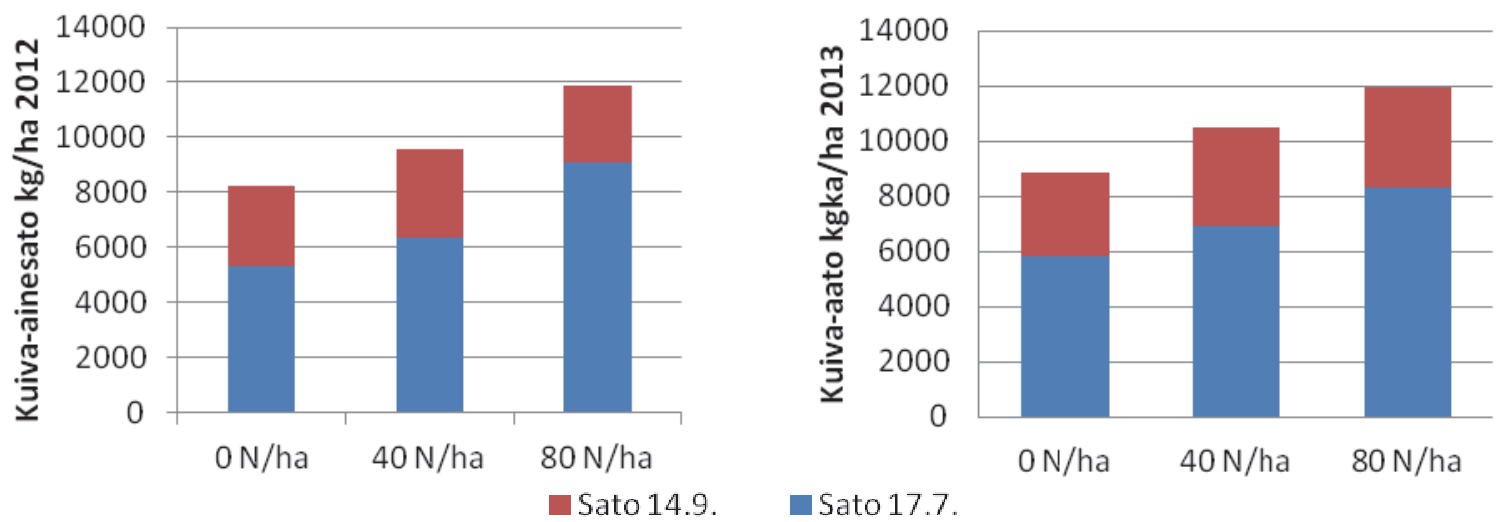

Rikkakasvien torjuntakokeissa havaittiin linuroni tehokkaimmaksi herbisidiksi (Kuva 8.). Myös luomumenetelmillä päästiin lähes samoihin tuloksiin kuin herbisideillä (Kuva 9.). Luomumenetelmien työläyden ja torjunta-ajankohdan oikean ajoituksen tarkkuuden takia niitä voi suositella vain jos sadosta saatava tulo on merkittävästi parempi kuin tavanomaisen tuotannon menetelmillä saatu tulo.

Kuva 8. Siankärsämön osuus (\%) kasvustossa eri herbisideillä perustamisvuotena.

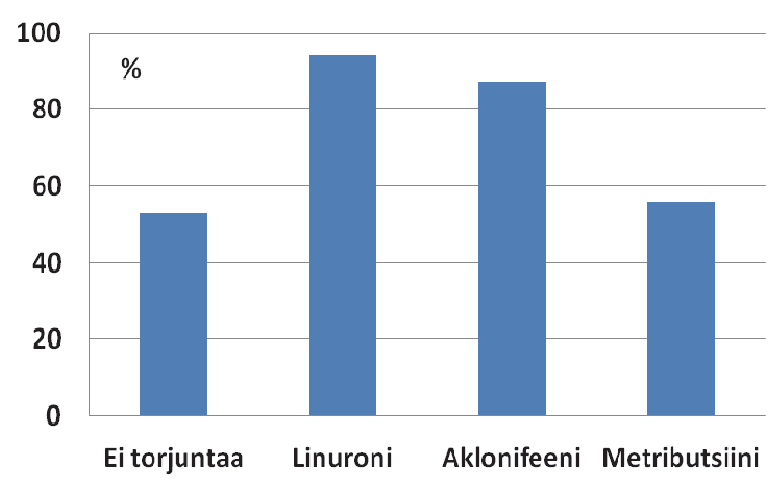

Kuva 9. Siankärsämön osuus (\%) kasvustossa eri torjuntamenetelmillä ensimmäisenä satovuotena. Kuminan torjunta-aine $=$ linuroni.

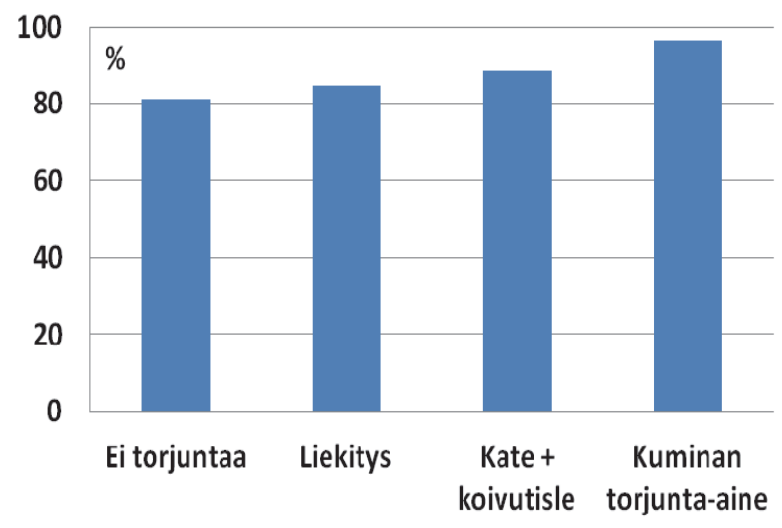


Piharatamosta korjattiin siemensato kasvukauden 2013 lopulla (Kuva 10.). Vaikka satoerot typpilannoitustasojen välillä näyttävät suurilta, ne eivät ole tilastollisesti merkittäviä.

Kuva 10. Piharatamon typpilannoitukset ja siemensadot kasvukaudella 2012 ja 2013
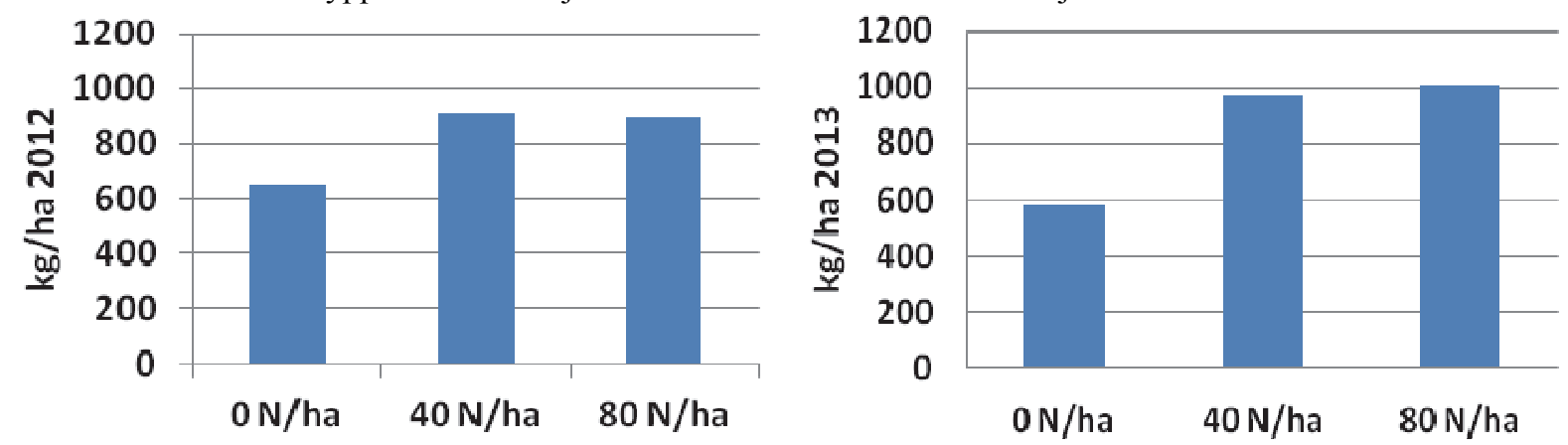

Rikkakasvien torjuntakokeissa havaittiin linuroni tehokkaimmaksi herbisidiksi myös piharatamolla (Kuva 11.). Luomumenetelmien teho oli merkittävästi huonompi ensimmäisenä satovuotena, vaikka ratamon peittävyys oli parempi kuin perustamisvuotena (Kuva 12.).

Kuva 11. Piharatamon osuus (\%) kasvustossa eri Kuva 12. Piharatamon osuus (\%) kasvustossa eri herbisideillä perustamisvuotena. torjuntamenetelmillä ensimmäisenä satovuotena. Kuminan torjunta-aine=linuroni.
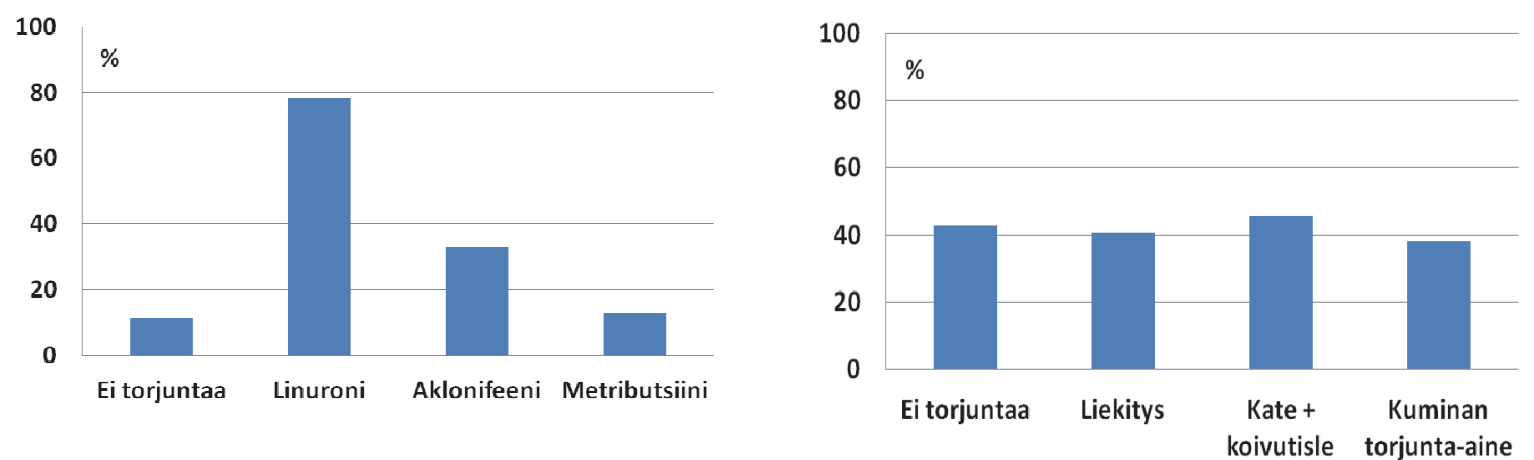

Sekä siankärsämöllä että piharatamolla rikkakasvien osuus koealoissa oli perustamisvuotena suurempi kuin ensimmäisenä satovuotena. Erityisesti pienisiemenisen piharatamon alkukehitys on hidasta, nuoren kasvuston kilpailukyky on heikko ja kuiva alkukesä voi hidastaa merkittävästi taimettumista sekä lisätä aukkoisuutta, jolloin rikkakasvit pääsevät helposti leviämään. Käytössä olevat torjunta-aineet on lisäksi levitettävä ennen viljelykasvin taimettumista, jolloin myöhemmin kasvukaudella ilmestyvät rikat voivat olla suuri ongelma.

\section{Johtopäätökset}

Suomalainen erikoiskasvituotanto on tyypillisesti pienimuotoista, jopa kotipuutarhamittakaavaista toimintaa. Kuminan tuotannon kasvu on osoittanut, että kun tuotanto on kilpailukykyistä sen nopeakin kasvu on mahdollista.

Suomessa tuotetun väinönputken satotasot ovat täysin kilpailukykyiset Keski-Euroopan satoihin verrattuna. Lisäetuna on väinönputken pohjoinen laatu, mikä näkyy juurisadon suurena fellandreenipitoisuutena. Väinönputken tuotanto on toteutettavissa tavanomaisella maatilan konekannalla, joten lähtökohdat kuminan kaltaiseen menestykseen ovat olemassa.

Siankärsämön ja piharatamon suhteen tilanne on haasteellisempi. Kysyntä on väinönputkea alhaisempaa, eikä laajamittaista tuotantoa jonka kokemuksia voisi hyödyntää juuri ole. Näillä erikoiskasveilla on kuitenkin käyttösovelluksia mm. kosmetiikka- ja hyvinvointituotteissa joiden globaalit markkinat kasvavat nopeasti. Suomi voisi olla näiden erikoiskasvien tuottajana eturintamassa. Viljelytekniikan kehittämisessä kriittisenä kohteena pidetty rikkakasvien torjunta olemassa olevilla menetelmillä on täysin mahdollista tavanomaisessa tuotannossa, luomutekniikat vaativat kuitenkin jatkokehittämistä. Toinen tärkeä jatkokehittämisen kohde on sadonkorjuutekniikka. 


\section{Viitteet}

Bomme, U. 2001. Kulturanleitung für Engelwurz. 4th Edition. Bayerische Landesanstalt für Landwirtschaft (LfL), Freising, Deutschland.

Ebert, K. 1982. Arznei- und Gewürzpflanzen: ein Leitfaden für Anbau und Sammlung. Wissenschaftliches Verlagsgesellschaft mbH Stuttgart. 2nd ed. Germany

Ekbladh, G., Ekelund-Axelson, L., Mattsson, B. 1993. Ekologisk grönsaksodling : en företagsstudie. Ekologiskt lantbruk 16. Sveriges lantbruksuniversitetet, Avdelning för Ekologiskt Lantbruk,. Uppsala

Galambosi, B., Roitto, M. 2006. Pohjoisessa kasvatettujen yrttien aromisuus. Maa- ja elintarviketalous 84 . MTT, Jokioinen 